\title{
Przyjęcie do wykonania kary orzeczonej przez sądy państwa obcego a prawo łaski
}

\begin{abstract}
In this paper the author considers the connotations between the presidential pardon applied under the Constitution of the Republic of Poland and the judgments of foreign courts sensu largo. This article deals with issues that are on the borderline between constitutional law, criminal law (substantive and procedural) and international law, both public and criminal. The analysis of literature and jurisprudence in this respect allows the author to conclude that the right of grace is significantly limited by international law, due to the international agreements and art. 9 of the Polish Constitution. The author argues that the acceptance of a punishment to be enforced (ordered by a foreign court) excludes the possibility of applying presidential law of clemency to the perpetrator, unless an international agreement (or custom) provides otherwise.
\end{abstract}

Keywords: presidential pardon, public international law, international criminal law, criminal law, criminal procedure, extradition

\section{Wprowadzenie}

Łaska oraz wypływające z niej prawo łaski wydają się być równe wiekiem naszej cywilizacji. Jednym z najbardziej wyrazistych przykładów zastosowania tego prawa jest okazanie łaski Barabaszowi przez Poncjusza Piłata².

${ }^{1}$ przemyslawkrawczyk3@gmail.com, nr tel. +48 667484 335, https://orcid.org/0000-0002-5462-3540.

${ }^{2} \mathrm{Z}$ uwagi na charakter tego artykułu historyczne tło stosowania prawa łaski w Polsce, jak i na świecie zostaje poza orbitą rozważań. Niemniej jednak warto zwrócić uwagę na inter alia K. KozŁowski: Prawo taski Prezydenta RP. Warszawa 2013, s. 1-170 oraz A. Murzynowski: Ułaskawienie $w$ Polsce Ludowej. Warszawa 1965. Druga z wymienionych publikacji jest o tyle ciekawa, że z uwagi na okres jej powstania - za czasów słusznie już minionego systemu władzy - przedstawia instytucję prawa łaski w państwie socjalistycznym. 
Prawo łaski nie było obce także kodeksowi Hammurabiego ${ }^{3}$. Upływ wieków nie zmienił jednak zasady („zasady ogólnej” - można by się nawet posłużyć takim stwierdzeniem) w oparciu o którą stosowane jest ius agratiandi. Pozwalając sobie na - dość duże - uproszczenie, można ją zobrazować w sposób następujący - suweren (bądź osoba sprawująca funkcję „głowy państwa” w jego imieniu) stosuje prawo łaski, które polega na darowaniu skazanemu wykonania kary ${ }^{4}$. Na gruncie prawa rodzimego ułaskawienie jest jedna z prerogatyw prezydenta $\mathrm{RP}^{5}$. Polski ustrojodawca w art. 139 Konstytucji RP stanowi: „Prezydent Rzeczypospolitej stosuje prawo łaski. Prawa łaski nie stosuje się do osób skazanych przez Trybunał Stanu". Ów lakonicznie, niemalże ascetycznie, wyrażony przepis prawny stanowi materialną podstawę stosowania prawa łaski w Rzeczpospolitej. Ustrojodawca nie zdecydował się zdefiniować tejże instytucji, a jedynie ograniczył do opisania samej kompetencji głowy państwa ${ }^{6}$. Bez obawy o błąd można wskazać, że skutki ułaskawienia tyczą się prawa karnego materialnego ${ }^{7}$. Niemniej jednak na próżno doszukiwać się rozwinięcia powyższej konstytucyjnej normy w Kodeksie karnym ${ }^{8}$. Niewątpliwie rację ma K. Kozłowski, który uważa, że na ten czas prawo łaski nie służy jako instrument „przebaczenia winy”. Powoływany autor wskazuje, że de lege lata ułaskawienie jednostki nie powoduje przecież jej uniewinnienia poprzez unieważnienie wydanego $\mathrm{w}$ jej sprawie orzeczenia. W literaturze wskazuje się, iż ułaskawienie może nastąpić poprzez zastosowanie łaski całkowitej (czyli darowanie kary lub karnoprawnych skutków skazania w całości) bądź niczym nieskrępowane warunkowe zawieszenie wykonania kary, warunkowe zwolnienie z odbywania reszty kary albo złagodzenie skutków kary ${ }^{9}$, np. zmianę środka karnego na rodzajowo ła-

${ }^{3}$ Zob. H. Weinofe: Legislative Pardons. Another View. "California Law Review” 1939, s. 388-389 oraz J. Harris, L. ReDmond: Executive Clemency: The Lethal Absence of Hope. “American University Criminal Law Brief” 2007, s. 3.

${ }^{4}$ Bądź zmianie rodzaju kary na łagodniejszy, ewentualnie zmianie warunków jej odbywania. Nie decydując się jednak w niniejszym artykule na rozważania historyczne w tym przedmiocie - z rozmaitych powodów - konieczne jest dokonanie powyższego uproszczenia.

${ }^{5}$ R. Balicki: Komentarz do art. 139 Konstytucji Rzeczpospolitej Polskiej z 1997 r. W: Konstytucje Rzeczpospolitej oraz komentarz do Konstytucji RP z 1997 r. Red. J. Boć. Wrocław 1998, s. 225.

${ }^{6}$ Por. K. KozŁowski: Konstytucyjny wymiar prawa łaski. W: IDEM: Prawo...

7 L. WiLk: Prawo taski a sprawiedliwość karania - refleksja filozoficznoprawna. „Problemy Prawa Karnego" 2000, nr 23, s. 23 i nast.

${ }^{8}$ Ustawa z dnia 6 czerwca 1997 r. - Kodeks karny (Dz.U. 1997, nr 88, poz. 553 ze zm.).

${ }^{9}$ K. Kozłowski stosuje swoistą typologię prawa łaski. Dzieli ułaskawienie na pełne bądź niepełne oraz warunkowe lub bezwarunkowe. Pełne prawo łaski ma się sprowadzać do tego, że skazanemu darowana jest cała orzeczona kara - pozostała do wykonania i orzeczone środki karne bądź ma polegać na darowaniu w całości środków karnych albo samej kary. Zgodnie z poglądem K. Kozłowskiego ułaskawienie niepełne może polegać na 
godniejszy ${ }^{10}$. Polski ustawodawca $\mathrm{w}$ rozdziale 59 Kodeksu postępowania karnego $^{11}$ uregulował jedynie kwestie proceduralne, nie wprowadzając

zmianie kary na rodzajowo łagodniejszą. Natomiast ułaskawienie warunkowe będzie się równać postawieniu przed skazanym swojego rodzaju warunków, od których spełnienia prezydent uzależni skorzystanie ze swojej prerogatywy. Oczywiste jest, że głowa państwa nie będzie związana tymi warunkami. Opozycją do powyższego ma być ułaskawienie bezwarunkowe, które nigdy nie będzie obwarowane żadnym warunkiem koniecznym do spełnienia w celu zastosowania prawa łaski, zob. K. KozŁowski: Treść kompetencji Prezydenta $R P w$ świetle ustawy zasadniczej. W: IDEM: Prawo...

10 Zob. K. Nowicki: Postępowania następcze. W: Proces karny. Red. J. SKоRUPKa. Warszawa 2017, s. 781. Wysoce dyskusyjna jest możliwość zastosowania prawa łaski o charakterze abolicji indywidualnej, zob. szerzej K. KozŁowsкi: Treść kompetencji Prezydenta RP w świetle ustawy zasadniczej. W: IDEM: Prawo...; P. Kardas, J. GIEzEK: Konstytucyjne podstawy prezydenckiego prawa łaski a możliwość stosowania tzw. abolicji indywidualnej. Pal. 2016, nr 1-2, s. 21-39; W. Makowski: Prawo karne. Część ogólna. Warszawa 1920, s. 420. Poglądu odrzucającego możliwość stosowania prawa łaski jako aktu abolicji indywidualnej nie można określić jako novum, już w dwudziestoleciu międzywojennym E. Krzymuski wyraził negatywną opinię w tym przedmiocie, zob. E. Krzymuski: System Prawa Karnego. T. 1. Kraków 1921, s. 299. Zob. K. Nowicki: Postępowania następcze... oraz M. Wiszowaty: Prawo łaski Prezydenta III RP jako realizacja funkcji przedstawiciela suwerennego narodu oraz strażnika bezpieczeństwa państwa. Uwagi po uchwale składu siedmiu sędziów Sądu Najwyższego z dnia 31 maja 2017 r. (sygn. akt I KZP 7/17). „Gdańskie Studia Prawnicze” 2018, s. 507-520; R. KмIEсIK: Jeszcze raz w sprawie abolicji indywidualnej. Prok. i Pr. 2017, nr 12, s. 5-11 oraz podane w powyższych pozycjach orzecznictwo i literatura. Konieczne jest także wskazanie, że w doktrynie zwolenników znajduje pogląd odrębny od powyższego. S. Waltoś pisze, że „prezydent może skorzystać z prawa łaski w każdej sprawie o przestępstwo i wykroczenie, również przed prawomocnym skazaniem, mimo że praktyka nie zna, jak na razie, wyjątków od ułaskawienia dopiero po uprawomocnieniu się wyroku skazującego; mówiąc inaczej, dopuszczalne jest ułaskawienie w postaci abolicji indywidualnej” - zob. S. WaLtoś: Proces karny. Zarys systemu. Warszawa 2002, s. 552. T. Grzegorczyk podzielając podobny pogląd, wskazuje, że w ramach ułaskawienia „nie jest wyłączona [...] tzw. abolicja indywidualna, a więc uwolnienie od odpowiedzialności jeszcze przed prawomocnym skazaniem" - zob. T. GrzegorczyK: Kodeks postępowania karnego. Komentarz. Warszawa 2008, s. 1184. Podobny pogląd mają A. Murzynowski: Ułaskawienie..., s. 128; L. Gardocki: Prawo karne. Warszawa 1998, s. 193 i nast.; K. KaCzMArCZYK-KŁAK: Postępowanie ułaskawieniowe $w$ świetle Konstytucji RP na tle porównawczym. IN 2001, nr 3 s. 36 i nast.; S. StachowiaK: Ułaskawienie $w$ przepisach k.p.k. „Wojskowy Przegląd Prawniczy” 2000, nr 2, s. 3 i nast. Rozwinięcie kwestii prawa łaski jako przejawu abolicji indywidualnej w sposób znaczący wykroczyłoby poza ramy niniejszego artykułu. Wszak stanowiska doktryny $\mathrm{w}$ tym przedmiocie są skrajnie opozycyjne, a samo ich przytoczenie spowodowałoby znaczne rozrośnięcie się niniejszej pracy. Przegląd tychże poglądów zawiera monografia K. KŁączyńsKa-KŁaK: Prawo taski w Polsce na tle porównawczym. Dawniej i współcześnie. Rzeszów 2013, s. 431 i nast. W związku z powyższym Autor w niniejszym artykule będzie rozważał kwestię możliwości zastosowania prawa łaski wobec jednostki, która została skazana prawomocnym orzeczeniem sądu.

11 Ustawa z dnia 6 czerwca 1997 r. - Kodeks postępowania karnego (Dz.U. 1997, nr 89, poz. 555 ze zm.). 
żadnych ograniczeń podmiotowo-przedmiotowych prawa łaski. Słusznie zatem wskazuje P. Czarny, pisząc, iż ustawodawca w k.p.k. uregulował tzw. tryb kodeksowy procedury ułaskawienia ${ }^{12}$. Możliwe jest zatem, ażeby prezydent pominął całkowicie przewidzianą w k.p.k. procedurę i zastosował prawo łaski wobec skazanego zgodnie ze swoim uznaniem ${ }^{13}$. Wszak nie istnieją prawne środki rewizji decyzji prezydenta, zatem - jeśli wydano decyzję pozytywną, tj. udzielającą prawa łaski - będzie ona ostateczna ${ }^{14}$. Słuszny zatem jest pogląd J. Bocia, który pisze, że „stosowanie prawa łaski nie polega na wymierzaniu sprawiedliwości i dlatego nie jest działaniem z obrębu władzy sądowniczej (sprawiedliwość w tej sprawie została wymierzona), ale jest z obszaru władzy wykonawczej. Ponieważ kompetencja polegająca na stosowaniu prawa łaski była i jest związana w porządkach prawnych i państwowych wyłącznie z głową państwa, jej realizacja (nierealizacja) nie jest i nie może być kontrolowana"15. Trafnie zauważa D. Górecki, że „prezydent dysponuje tym prawem na podobnych zasadach jak król w monarchii”" ${ }^{16}$. R. Mojak wskazuje, iż prawo łaski w dzisiejszym jego rozumieniu jest wypadkową tradycji suwerenności monarchy będącej jedną z klasycznych cech suwerenności naczelnej władzy wykonawczej ${ }^{17}$. W. Kwiatkowski uważa, że prawo łaski stanowi swoisty „wentyl bezpieczeństwa”, który znajdzie zastosowanie „w nieokreślonych z góry, nadzwyczajnych sytuacjach - powstałych po popełnieniu czynu wypełniającego znamiona przestępstwa" ${ }^{18}$. Trafnie zostało podniesione w orze-

12 P. Czarny: Komentarz do art. 139 Konstytucji Rzeczpospolitej Polskiej. W: Konstytucja Rzeczpospolitej Polskiej. Komentarz. Red. P. Tuleja. LEX 2019.

${ }^{13}$ Adherenci poglądu o możliwości zastosowania aktu łaski jako przejawu tzw. abolicji indywidualnej wskazują, że jeśli taka sytuacja by wystąpiła in concreto, sąd winien postępowanie karne umorzyć na podstawie art. 17 § 1 pkt 11 k.p.k. - tak K. KACZMARCZYK-KŁAK: Prawo..., s. 438.

${ }_{14}$ Zasadność decyzji prezydenta może być rozważana jedynie w kategoriach politycznych, jednakże z uwagi na prawniczy charakter niniejszej pracy polityczne skutki ułaskawienia pozostają poza orbitą rozważań.

15 J. Boć: Komentarz do art. 139 Konstytucji Rzeczpospolitej z 1997 r. W: Konstytucje..., s. 225.

16 D. GóRecki: Prezydent Rzeczypospolitej Polskiej. W: Polskie prawo konstytucyjne. Red. IDEm. Warszawa 2015, s. 191; podobnie A. ChorążewsKa: Model prezydentury w praktyce politycznej po wejściu w życie Konstytucji RP z 1997 r. Warszawa 2008, s. 249; R. Matajny: Prezydent RP. W: Polskie prawo konstytucyjne na tle porównawczym. Red. Idem. Warszawa 2013, s. 493; B. BanaszaK: Prawo konstytucyjne. Warszawa 2015, s. 273; P. KIERońcZYK: Prezydent RP - zadania i kompetencje. W: Leksykon prawa konstytucyjnego. 100 podstawowych pojęć. Red. A. SzMYT. Warszawa 2016, s. 295.

17 R. MоJAK: Instytucja Prezydenta RP w okresie przeksztatceń ustrojowych 1989-1992. Warszawa 1994, s. 249-250.

18 W. KwiatKowski: Prawo taski na poziomie stanowym w USA. „Zeszyty Prawnicze” 2016, s. 153 oraz W. KwiATKowsKi: Federalne prawo taski w Stanach Zjednoczonych Ameryki. „Zeszyty Prawnicze” 2015, s. 71. 
czeniu Sądu Najwyższego, że akt łaski winien być stosowany tylko wtedy, gdy konieczne jest uczynienie zadość poczuciu sprawiedliwości oraz ma się na względzie humanitaryzm ułaskawienia ${ }^{19}$, zaś nie można tym względom uczynić zadość w drodze postępowania jurydycznego ${ }^{20}$.

Mając powyższe na uwadze, nasunąc się mogą pewne wątpliwości związane $\mathrm{z}$ wykonaniem orzeczenia sądu karnego nie w jego klasycznym rozumieniu ( $\mathrm{tj}$. w sytuacji, gdy sąd wymierzający karę jest sądem polskim i kara jest następnie wykonywana na terytorium RP). Mowa tu o sytuacji, kiedy karę orzeczono przez organ nie podlegający polskiej jurysdykcji, zaś została ona przyjęta do wykonania na terytorium $\mathrm{RP}^{21}$. Nasuwa się zatem pytanie, czy prezydent RP może zastosować prawo łaski wobec osoby, której kara została oddana do wykonania na terenie RP, zaś podstawą jej wykonania jest orzeczenie organu obcego, nie podlegającego polskiej jurysdykcji. Innymi słowy, czy możliwe jest ingerowanie przez głowę państwa w wymiar sprawiedliwości sprawowany przez organy nie znajdujące się pod władztwem jurysdykcyjnym Rzeczpospolitej?

${ }^{19} \mathrm{Na}$ marginesie warto nadmienić, że w doktrynie podnoszone są głosy, jakoby prawo do ubiegania się o ułaskawienie miało wchodzić w zakres ochrony podstawowych praw człowieka. Jest to jednak problem niezwykle skomplikowany, wszak wymaga udzielenia odpowiedzi na pytanie, z czego miałoby owo prawo wynikać. Należy się oczywiście zgodzić z poglądem, że z uznanego na skalę międzynarodową zakazu tortur wynika nakaz stosowania - na każdym etapie realizowania ius puniendi - prawa w zgodności z humanitarnymi standardami, czy to wypracowanymi w danym państwie, czy w zgodzie z międzynarodowoprawnymi wzorcami. Niemniej jednak plasowanie wśród praw człowieka prawa do ubiegania się o ułaskawienie jest raczej chybione. Należy się raczaj zgodzić z K. Kaczmarczyk-Kłak, która wskazuje, że poza przypadkiem, o którym mowa w art. 6 ust. 4 Międzynarodowego Paktu Praw Obywatelskich i Politycznych otwartego do podpisu w Nowym Jorku dnia 19 grudnia 1966 r. (Dz.U. 1977, nr 38, poz. 167), sama możliwość ubiegania się o ułaskawienie nie może zostać uznana za prawo człowieka - zob. K. KaCZMARCZYK-KŁAK: Ułaskawienie w prawie polskim a Międzynarodowy Pakt Praw Obywatelskich i Politycznych oraz Konwencja o ochronie praw człowieka i podstawowych wolności. „Problemy Współczesnego Prawa Międzynarodowego, Europejskiego i Porównawczego" 2012, vol. X, s. 174-175.

${ }^{20}$ Zob. Post. SN z dnia 2 maja 1975, II KO 5/75. OSP 1976, z. 4, poz. 73.

${ }^{21}$ Ustawodawca w Kodeksie postępowania karnego posługuje się określeniem „przyjęcie i przekazanie orzeczenia do wykonania”. Niemniej jednak nie można tracić z pola widzenia tego, że w zakres znaczeniowy określenia „wykonanie orzeczenia” czy też „przekazanie orzeczenia do wykonania” wchodzi zarówno „przekazanie sprawcy”, jak i „wykonanie kary". Co więcej, te elementy są immanentnie związane z wykonaniem (przekazaniem do wykonania) orzeczenia. Wszak nie jest możliwe, ażeby wykonywać karę na kimś bez uprzedniego przyjęcia orzeczenia do wykonania. Ponadto w celu wykonania kary - aby nie była bezprzedmiotowa i bezpodmiotowa - musi nastąpić przekazanie sprawcy. Innymi słowy - bez przekazania sprawcy i kary do wykonania na nim nie może być mowy o przekazaniu do wykonania orzeczenia. 
W doktrynie wskazuje się, że prezydenckie prawo łaski ma szeroki zakres podmiotowy swego działania. Możliwe jest zatem ułaskawienie skazanego, który na terenie Rzeczypospolitej tylko odbywa karę, zaś został skazany przez sąd zagraniczny ${ }^{22}$. Ów pogląd jest zarazem trafny i chybiony. Trafny w zakresie rozumienia „sądu zagranicznego” jako sądu państwa członkowskiego Unii Europejskiej, wszak na gruncie prawa UE Rada Europejska postanowiła, iż „Państwo wydające oraz państwo wykonujące mogą postanowić o amnestii lub zastosować ułaskawienie" ${ }^{23}$. Można wysunąć odważną, acz nie bezpodstawną tezę, że prezydenckie prawo łaski w przestrzeni obowiązywania i stosowania prawa Unii Europejskiej nie ulega żadnym ograniczeniom ${ }^{24}$. Jednakże owo stanowisko w zakresie przyjęcia do wykonania na terytorium RP kary orzeczonej przez sąd „państwa trzeciego" 25 bądź międzynarodowe sądy karne jest chybione.

\section{Prawo łaski wobec wyroku Sądu „Państwa Trzeciego”}

Każde państwo jest suwerenne. Każdy podmiot prawa międzynarodowego w stosunkach na arenie międzynarodowej winien kierować się zasadą dobrej wiary, będącej powszechnie uznaną zasadą ogólną prawa międzynarodowego ${ }^{26}$. Suwerenność sprowadza się nie tylko do kwestii

22 Zob. P. Czarny: Komentarz...; L. Gardocki: Prawo karne. Warszawa 1998, s. 193; Z. SIENKIEwicz: Ułaskawienie. W: Prawo karne materialne. Część ogólna i szczególna. Warszawa 2020, s. 491. W ramach już raczej ciekawostki aniżeli obowiązującego prawa można zauważyć, iż obecnie prawo łaski skonstruowane jest w niemalże analogiczny sposób do tego, jaki obowiązywał w czasach PRL, zob. W. ŚwIDA: Prawo karne. Warszawa 1978, s. 371-375 oraz podana tam literatura i orzecznictwo.

${ }^{23}$ Art. 19 ust. 1 Decyzji Ramowej Rady 2008/909/WSiSW z dnia 27 listopada 2008 r. o stosowaniu zasady wzajemnego uznawania wyroków skazujących na karę pozbawienia wolności lub inny środek polegający na pozbawieniu wolności - w celu wykonania tych wyroków w Unii Europejskiej [dalej jako: Decyzja Ramowa Rady Europejskiej], zob. https://eur-lex.europa.eu/legal-content/PL/TXT/?uri=celex\%3A32008F0909 [dostęp: 4.11.2020].

${ }^{24}$ Sporną kwestią może być to, czy sądy innego kraju członkowskiego można nazwać „sądami zagranicznymi” par excellence. Niemniej jednak na potrzeby niniejszego artykułu konieczne jest przyznanie racji temu uproszczeniu, wszak jej rozwinięcie mogłoby spowodować całkowite stracenie z pola widzenia zasadniczego przedmiotu niniejszego opracowania.

${ }^{25}$ Autor w tym miejscu pozwolił sobie na uproszczenie poprzez owo kumulatywne określenie mające za swój desygnat kolektyw państw nie będących członkami Unii Europejskiej.

${ }^{26}$ Zob. szerzej E. Lis: Zasada dobrej wiary w prawie międzynarodowym. „Studia Iuridica Lublinensia” 2016, vol. XXV(1), s. 17-46 oraz podana tam literatura i orzecznictwo. 
związanych z rozumieniem jej jako „suwerenności terytorialnej”" Zagadnienie to należy rozumieć w kontekście przymiotu suwerenności, który zgodnie z teorią państwa G. Jellinka stanowi jeden z elementów sine qua non bytu, który w rozumieniu teorii prawa konstytucyjnego i międzynarodowego może zostać uznany za państwa par excellence ${ }^{28}$. Państwo uprawnione będzie zatem do decydowania o losie - $\mathrm{w}$ ramach stanowionego przezeń prawa oraz obowiązującego go prawa międzynarodowego, ze szczególnym naciskiem na prawa człowieka - jednostki, która została postawiona przed sąd i skazana zgodnie z obowiązującym prawem. Nie powinno budzić większych wątpliwości to, że orzeczenia wydane przez właściwy i powołany do tego organ danego państwa stanowią emanację władzy państwowej w relacji państwo - jednostka. Co do zasady państwo $^{29}$, w którym sprawca popełnił czyn zagrożony pod groźbą kary, jest właściwe do wymierzenia mu za to odpowiedniej sankcji ${ }^{30}$. Zatem jeśli państwo to jest właściwe do wydania orzeczenia wymierzającego karę, to tym bardziej jest ono władne do wykonania orzeczonej kary. Ius puniendi stanowi jeden z elementów wchodzących w zakres władzy państwowej w relacji państwo - jednostka ${ }^{31}$. Jako wyjątkową - na gruncie prawa międzynarodowego - można określić sytuację, w której osoba zostaje wydana obcemu państwu w celu odbywania kary na jego terytorium. Doktryna wskazuje, że wpisuje się to w pojęcie ekstradycji ${ }^{32}$, która stanowi raczej

27 Zob. szerzej W. Czapliński, A. Wyrozumska: Prawo międzynarodowe publiczne. Warszawa 2014, s. 173-180 oraz W. GóralczYK, S. SAWicki: Prawo międzynarodowe publiczne. Warszawa 2004, s. 126 i nast., R. Rosicki: O suwerenności. „Przegląd Naukowo-Metodyczny. Edukacja dla bezpieczeństwa” 2010, nr 4, s. 63-72 oraz podane w przywołanych pozycjach orzecznictwo i literatura.

28 Zob. szerzej G. JeLLINEK: Allgemeine Staatslehre. Berlin 1914; J. KostuRbIEC: Nauka o państwie w myśli Georga Jellinka. Lublin 2015.

${ }_{29}$ Nieco inaczej - w opinii Autora - wygląda to w sytuacji popełnienia przez człowieka zbrodni międzynarodowej. Będzie jednak o tym mowa w dalszej części opracowania.

${ }^{30}$ Można to sprowadzić do zdania - czyj czyn zabroniony, tego kara. Innymi słowy od chwili popełnienia czynu zabronionego między sprawcą a państwem, gdzie ów czyn został popełniony, zachodzi „łącznik czynu”, inaczej można to nazwać „zasadą miejscowości czynu".

31 Jednym z przymiotów państwa jako takiego jest jego efektywność, co sprowadza się w dużym uproszczeniu - do efektywnego wykonywania władzy na danym terytorium. Nie powinno budzić większych wątpliwości, iż w zakres „wykonywania władzy” wchodzi przywilej (a nawet obowiązek) państwa do wymuszania respektowania prawa wewnątrz obowiązującego. Ius puniendi wpisuje się zatem w jedną z funkcji (uprawnień) jako pierwotnego podmiotu prawa międzynarodowego publicznego. Można jednak prowadzić, niemalże niekończące się, dywagacje na temat jego zakresu, właściwości i genezy. Zob. szerzej T. SCHEFfler: O ius puniendi uwag kilka. W: Varia doctrinalia. Red. Ł. MaCHAJ. Wrocław 2012, s. 37 i nast.

32 W. Czapliński, A. Wyrozumska: Prawo międzynarodowe publiczne..., s. 256. Ad vocem można zauważyć, iż pojęcie „ekstradycji” na gruncie prawa międzynarodowego pub- 
wyjątek aniżeli regułę. Nierzadko państwa ex lege zakazują ekstradycji swoich obywateli ${ }^{33}$. Przejęcie sprawcy, czy też przyjęcie przez państwo obce do wykonania kary, jest rzadkością. Zdarza się jednak, że z jakiś powodów, czy to penologicznych, czy też osobistych, odbywanie kary na terytorium państwa trzeciego nie tylko wpłynie na lepszą prognozę kryminologiczną sprawcy, ale także poprawi jego szanse na resocjalizację (np. ze względu na możliwość bezpośredniego kontaktu z rodziną) ${ }^{34}$. Państwa często posiadają wewnętrzne regulacje pozwalające na wystosowanie do organów państwa trzeciego - odpowiednimi ścieżkami - swoistego rodzaju prośby dotyczącej możliwości przejęcia do wykonania orzeczenia wydanego przez odpowiednie organy tegoż państwa wobec jednostki będącej obywatelem państwa występującego. Na gruncie obecnie obowiązujących przepisów, jeżeli wobec obywatela polskiego zostanie orzeczona kara za granica, minister sprawiedliwości w trybie przepisów rozdziału 66 k.p.k. może wnioskować o wydanie go w celu odbywania orzeczonej mu kary przez sąd państwa trzeciego na terytorium $\mathrm{RP}^{35}$. Zgodnie $\mathrm{z}$ art. 114

licznego wydaje się być bardzo szeroko - wręcz dowolnie - używane. Nie będzie raczej błędem stwierdzenie, iż sytuacja jednostki, ale także państwa jest diametralnie różna pod względem chociażby zakresu władztwa państwowego przy wydaniu jednostki przed sądy innego państwa, jak również przy przyjęciu kary do wykonania. W literaturze przedmiotu wskazuje się na jej dwa rodzaje, a mianowicie ekstradycję czynną (mającą miejsce, gdy państwo A wydaje jednostkę państwu B) oraz ekstradycję bierną (która oznacza sprowadzenie jednostki w celu jej osądzenia, tzn. państwo B wnioskuje do państwa A o wydanie osoby, która po udzieleniu wymaganej zgody zostaje wydana przed sąd państwa wnioskującego). W polskim Kodeksie postępowania karnego przykładem ekstradycji biernej są normy rozdziału 65 k.p.k., zaś czynnej - rozdziału 64 k.p.k. Zob. szerzej M. PŁAchta: Zagadnienia ekstradycyjne w prawie polskim. „Studia Europejskie” 1999, nr 2, s. 74 i nast. oraz podana tam literatura. Konieczne jest jednak odróżnienie ekstradycji rozumianej jako przejęcie przez państwo o to wnioskujące osoby podejrzanej sensu largissimo (upraszczając - ekstradycji materialnej, wszak to od prawa materialnego karnego państwa przyjmującego będzie zależeć odpowiedzialność karna jednostki) od przyjęcia skazanego (ekstradycji wykonawczej, bowiem stanowi ona jedynie czynność techniczną, sprowadzającą się do wykonania kary).

${ }_{33}$ Taka sytuacja ma miejsce w Polsce, gdzie ekstradycja została zakazana na mocy woli ustrojodawcy zgodnie z art. 59 ust. 1 Konstytucji RP. Oczywiście zakaz ten nie ma charakteru absolutnego - wyjątki zostały przewidziane przez ustrojodawcę w art. 59 ust. 2 i 3 Konstytucji RP.

34 Pozwalając sobie w tym miejscu na pewną dygresję, można wskazać, iż wydanie skazanego innemu państwu w celu wykonania przez nie jego kary ma też zapewne uzasadnienie ekonomiczne. Wszak w tej sytuacji w lwiej części państwo trzecie obarczane jest kosztami wykonania kary.

${ }^{35}$ Konieczne jest wskazanie, iż te przepisy mają charakter subsydiarny. Wszak kiedy ową materię reguluje umowa międzynarodowa między RP a państwem czynu, to ma ona pierwszeństwo przed unormowaniami kodeksowymi. Zob. szerzej P. HofMański, E. SADZIK, K. ZgryzeK: Kodeks postępowania karnego. Komentarz do artykutów 468-682. T. III. Red. P. HofmańsKI. Wyd. 4. Warszawa 2012. 
§ 1 k.k. kara orzeczona za granicą nie stanowi przeszkody do wszczęcia postępowania karnego o ten sam czyn zabroniony przed sądami polskimi (tzw. zasada irrelewantności wyroku państwa obcego $\left.{ }^{36}\right)$. Ustawodawca wprowadził w art. $114 \S 3$ k.k. katalog sytuacji wyjątkowych, których wystąpienie powoduje wyłączenie stosowania zasady ogólnej przewidzianej w $§ 1$ tejże jednostki redakcyjnej ustawy karnej. Jednakże uwagę w szczególności zwraca swoistego rodzaju wyjątkowa sytuacja, jaką przewiduje ustawodawca w art. $114 \S 4$ k.k. Nakłada on na sąd polski obowiązek „dostosowania” orzeczonej za granica polskiemu obywatelowi kary ${ }^{37}$. Trafnie zostało zauważone, że ,sąd polski [...] adaptuje to rozstrzygnięcie [sądu państwa skazania - P.K.] na grunt prawa polskiego. Należy jednak zaznaczyć, że chodzi jedynie o dostosowanie wyroku do ustawodawstwa państwa, w którym ma on być wykonany, a nie o wymierzenie kary od nowa"38. De lege lata w stosunku do obywateli państw członkowskich UE stosuje się zapisy przewidziane w Decyzji Ramowej Rady Europejskiej, zaś w innych przypadkach należy zbadać in concreto, czy państwo trzecie i RP są związane bi- albo multilateralną umową międzynarodową mającą za swój przedmiot przekazywanie skazanych między państwami (np. Konwencja o przekazywaniu skazanych z dnia 21 marca 1983 r.). Na marginesie powinno powstać pytanie, jak powyższe ma się do rozważań będących przedmiotem niniejszego artykułu. Otóż ma to znaczenie nie do przecenienia. Obecnie pewna część praktyków, a także - co ze smutkiem trzeba przyznać - teoretyków prawa zdaje się ignorować zasady płynące z prawa międzynarodowego publicznego oraz konsekwencje, jakie mają one - a przynajmniej powinny mieć - na gruncie rodzimego stosowania prawa oraz wymiaru sprawiedliwości. Art. 9 Konstytucji RP stanowi, iż „Rzeczpospolita Polska przestrzega wiążącego ją prawa międzynarodowego"; co za tym idzie - zobowiązana jest do przestrzegania prawa płynącego z zasad ogólnych, a zwłaszcza tych, które mają charakter norm ius cogens. Nie ulega wątpliwości, że przymiot bezwzględnego obowiązywania można przyznać zasadzie suwerenności, suwerennej równości państw oraz dobrej wiary. Wszak bez obawy o błąd można stwierdzić, że wymie-

36 Zob. R. Stefański: Prawo karne materialne. Część ogólna. Warszawa 2008, s. 81-82.

37 Zob. Z. BARwINA: Przepis art. $114 \$ 4$ kodeksu karnego $w$ świetle konwencji o przekazywaniu osób skazanych z dnia 21 marca 1983 r. „Czasopismo Prawa Karnego i Nauk Penalnych" 2009, z. 1, s. 69-77.

38 J. Ragalewski: Komentarz do art. 114 k.k. W: Kodeks karny. Część ogólna. Komentarz. Red. G. Bogdan et al. Kraków 2004, s. 1153. Zob. także N. KŁąCZyŃsKa: Komentarz do art. 114 k.k. W: Kodeks karny. Część ogólna. Komentarz. Red. J. GIEzEK. Warszawa 2007, s. 694; A. MareK: Kodeks karny. Komentarz. Warszawa 2007, s. 253; B. KunicKA-MichalsKa: Komentarz do art. 114 k.k. W: Kodeks karny. Część ogólna. Komentarz. Red. G. Rejman. Warszawa 1999, s. 1385. Podobny pogląd został także wyrażony w post. SA w Krakowie z dnia 8 kwietnia 2010 r., II AKz 114/10. LEX nr 590590. 
nione normy są trzonem wszelkich relacji prawno-międzynarodowych. Jeśli zatem sąd państwa obcego wydaje wyrok, który wchodzi w zakres ius puniendi państwa skazania, państwo będące stroną ekstradycji wykonawczej, tj. przyjmujące orzeczenie, a co za tym idzie karę do wykonania (tu RP), jest zobowiązane ją wykonać, nie dokonując $\mathrm{w}$ trakcie procesu wykonywania tejże kary żadnych ingerencji, które by zaprzepaściły samą istotę i cel tejże punitywnej represji państwa wobec jednostki. Wszak wszelkie nieuprawnione ingerencje państwa wykonującego karę będą stanowić naruszenie prawa państwa obcego do ukarania sprawcy czynu zabronionego ${ }^{39}$. Nawet jeśli owym sprawcą byłby obywatel polski, w tym zakresie, jeśli chodzi o jego ukaranie, prawo łaski nie może zostać zastosowane. Na Rzeczpospolitej ciąży zobowiązanie międzynarodowe, które musi zostać zachowane. Jego naruszenie stanowiłoby delikt na gruncie prawa międzynarodowego ${ }^{40}$. Sytuacja wyglądałaby jednak zgoła inaczej, gdyby to Rzeczpospolita wystąpiła o ekstradycję materialną obywatela polskiego, tj. przed wydaniem na sprawcę wyroku w państwie popełnienia przestępstwa, w celu osądzenia go na terenie jego ojczyzny. Jeśli bowiem państwo popełnienia przestępstwa zgodziłoby się na wydanie jego sprawcy Polsce, to wówczas niejako zrzeka się ono części swojej suwerennej władzy w zakresie ius puniendi na korzyść państwa polskiego ${ }^{41}$. W takiej sytuacji, gdyby doszło do skazania, prezydent byłby władny zastosować prawo łaski, wszak byłoby to zgodne z prawem międzynarodowym, niemniej jednak mogłoby pozostawić pewien niesmak na arenie politycznej. Jednakże z uwagi na charakter niniejszego artykułu konsekwencje polityczne takiej decyzji pozostają poza orbitą prowadzonych tutaj rozważań.

39 W polskiej judykaturze podnosi się, iż „Przejęcie do wykonania kar, które w państwie wydania orzeczenia nie zostały połączone, oznacza obowiązek wykonania każdej z tych kar”. Zgadzając się z tą interpretacją, dozwolone jest stosowanie argumentacji ad minori ad maius, którą to można sprowadzić do następującego - skoro nie można kar łączyć, to tym bardziej nie można od kar zwalniać. Zob. post. SN z dnia 29 listopada 2006 r., I KZP 26/06. OSNKW 2006, nr 12, poz. 109; LEX nr 203987.

${ }^{40} \mathrm{O}$ odpowiedzialności państwa na gruncie prawa międzynarodowego zob. W. Czapliński, A. Wyrozumska: Prawo międzynarodowe publiczne..., s. 733 i nast. oraz podane tam orzecznictwo i literatura.

${ }^{41}$ Państwo występujące o wydanie swojego obywatela czy też osobę obywatelstwa obcego działa w myśl zasady aut dedere, aut iudicare. Jest ona powszechnie uznaną zasadą prawa międzynarodowego, która obliguje państwa do działania w celu sprawnego wymierzenia sprawiedliwości. Zob. szerzej W. CzAPLIŃsKi, A. WyrozumsKa: Prawo międzynarodowe publiczne..., s. 298 i nast.; a także w zakresie zastosowania tej zasady w aspekcie uznania wyroków karnych zob. K. Polit-LangIERowicz: Wzajemne uznawanie orzeczeń karnych między państwami Unii Europejskiej. Prok. i Pr. 2008, nr 3, s. 82-96 oraz podana $\mathrm{w}$ przywołanych publikacjach literatura i orzecznictwo. 
Na marginesie powyższych rozważań uzasadnione będzie postawienie pytania, które prawo będzie miało zastosowanie wobec środka probacyjnego $\mathrm{w}$ postaci warunkowego przedterminowego zwolnienia $\mathrm{z}$ odbywania reszty orzeczonej kary ${ }^{42}$, umożliwiającego de facto skrócenie czasu jej wykonywania. W tym przypadku odpowiedź będzie zupełnie odmienna aniżeli w przypadku przedmiotu ułaskawienia. Bowiem zastosowanie będą miały przepisy regulujące środki związane z poddaniem sprawcy próbie obowiązujące na terytorium państwa, które przyjęło karę do wykonania. Dziać się tak będzie z dwóch powodów. Po pierwsze, tak jak w przypadku „ekstradycji materialnej”, państwo wydające zrzeka się na korzyść państwa przyjmującego pewnego zakresu władzy, wynikającego z ius puniendi, pozwalającego w odpowiedni dla tegoż prawa sposób modelować wykonanie kary ${ }^{43}$. Bez obawy o błąd można skonstatować, iż możliwość poddania sprawcy próbie winna pozostać w gestii państwa przyjmującego, wszak to ono czuwa nad przebiegiem wykonania kary. Organy wykonujące władzę państwową wobec skazanego w imieniu państwa przyjmującego są kompetentne do wydania takiej decyzji ${ }^{44}$, bowiem to one dysponują najszerszą wiedzą na temat wykonania przez skazanego kary, jego postępów czy też prognostyk resocjalizacyjnych, a na podstawie tego są właściwie uposażone do oceny danego przypadku in concreto. Po wtóre, jak wynika z samego charakteru środków probacyjnych, ich celem jest

42 A. Marek podnosi, że warunkowe przedterminowe zwolnienie z odbywania reszty kary nie jest środkiem probacyjnym sensu stricto. Zgodnie z tym poglądem środek ten nie stanowi reakcji na przestępstwo związane z poddaniem sprawcy próbie. Wszak w klasycznym anglosaskim ujęciu wyróżnia się probation (polskim odpowiednikami będą warunkowe umorzenie postępowania oraz warunkowe zawieszenie wykonania kary) oraz parole (warunkowe przedterminowe zwolnienie). Pierwsze z wymienionych mają być (i są) stosowane przed wykonaniem kary, natomiast drugie jest stosowane już w procesie jej wykonania. Niemniej jednak już sam A. Marek zauważa, że warunkowe przedterminowe zwolnienie winno być zaliczane do środków związanych z poddaniem sprawcy próbie, „o czym przesądza warunkowy charakter zwolnienia, nakładanie na zwolnionego obowiązków próby i dozór kuratorski oraz uzależnienie skutków prawnych od wyniku próby"por. A. MareK: Prawo karne. Warszawa 2011, s. 309 oraz podana tam literatura. Więcej o środkach probacyjnych zob. S. Hypś: Komentarz do rozdziału VIII kodeksu karnego. W: Kodeks karny. Komentarz. Red. A. GrześKowiak. Legalis 2021; Z. SiENKIEWICZ: Środki związane z poddaniem sprawcy próbie. W: Prawo karne materialne. Część ogólna i szczególna. Red. M. Bojarski. Warszawa 2020, s. 415 i nast.; W. Wróbel, A. Zoll: Polskie..., s. 417 i nast.

${ }^{43}$ Analogiczna sytuacja będzie miała miejsce w przypadku np. wyboru typu zakładu karnego właściwego do odbywania kary czy systemu, w jakim owa kara będzie odbywana.

${ }^{44}$ W krajach Unii Europejskiej materia ta została uregulowana na poziomie unijnym organy państw członkowskich, które przyjęły karę do wykonania, oceniają (z zastrzeżeniem pewnych wyjątków) możliwość zastosowania środków probacyjnych podług ich własnego prawa (arg. ex art. 17 Decyzji Ramowej Rady Europejskiej). 
przede wszystkim - w dużym uproszczeniu - poddanie sprawcy próbie ${ }^{45}$, w sytuacji gdy spełnia on szczególne ustawowe wymogi. Zastosowanie środków probacyjnych (w tym także warunkowego przedterminowego zwolnienia z odbywania reszty kary) wobec skazanego obwarowane jest różnego rodzaju wymogami, które dana jednostka musi spełnić, ażeby ów środek został wobec niej zastosowany. Przede wszystkim konieczna jest pozytywna prognoza kryminologiczna sprawcy. W opozycji do powyższego stoi prawo łaski ${ }^{46}$, które nie jest „obostrzone” żadnymi szczególnymi przesłankami koniecznymi do spełnienia przez skazanego w celu możliwości jego zastosowania. Innymi słowy ułaskawienie sprawcy całkowicie zaprzepaściłoby sens orzeczonej kary jako faktu społecznego ${ }^{47}$, a ponadto spowodowałoby utracenie $\mathrm{z}$ pola widzenia celów kary in genere ${ }^{48}$ oraz znaczenia kary jako takiej ${ }^{49}$. W doktrynie wskazuje się, że środki związane z poddaniem sprawcy próbie są przejawem racjonalizacji karania ${ }^{50}$. Ich zastosowanie nie oznacza zakończenia stosowania wobec skazanego kary par excellence, bowiem, jak przewidziane jest chociażby przez polskie ustawodawstwo, istnieje możliwość odwołania udzielonego niejako „przywileju próby”. Zadziać się tak może w sytuacji, gdy narusza on rażąco porządek prawny bądź popełnia przestępstwo w trakcie okresu próby (arg. ex. art. 77 k.k. w zw. z art. 160 k.k.w. ${ }^{51}$ ). W sytuacji ułaskawienia de iure zwalnia się jednostkę z odbywania reszty kary czy kary w ogóle. Zatem zastosowanie przez polski organ konstytucyjny - prezydenta - pra-

${ }^{45}$ O charakterze i celach środków probacyjnych zob. szerzej w Z. SIENKIEWICZ: Środki zwiqzane z poddaniem sprawcy próbie. W: Prawo karne materialne..., s. 415 i n; L. GaRdocKI: Prawo karne. Warszawa 1998, s. 185 i nast.; W. ŚwIDA: Prawo karne..., s. 343 i nast.; W. Wróbel, A. Zoll: Polskie prawo karne. Część ogólna. Kraków 2014, s. 471 i nast. oraz podana w powyższych publikacjach literatura.

${ }_{46}$ Mowa tu oczywiście o prawie łaski zupełnym, które zakłada „ułaskawienie” skazanego polegające na zwolnieniu go z odbywania kary.

${ }^{47}$ M. CIEŚLAK: O węzłowych pojęciach zwiqzanych z sensem kary. NP 1969, nr 2, s. 203.

${ }^{48}$ Dokładne omówienie problematyki celów i funkcji kary znacząco wykracza poza ramy niniejszej publikacji. Zob. szerzej W. Wróbel, A. Zoll: Polskie..., s. 417 i nast.; Z. Sienkiewicz: W: Prawo karne materialne..., s. 347 i nast.; W. ŚwidA: Prawo karne..., s. 253 i nast.; L. GARDOCKI: Prawo..., s. 150 i nast. oraz podana tam literatura.

${ }^{49}$ Kara nie jest definiowana jednolicie na gruncie doktryny prawa karnego. Na rzecz prowadzonych tutaj rozważań Autor przyjmuje za właściwą definicję podaną przez prof. Z. Sienkiewicz, tj. „Kara (kryminalna) jest [to - P.K.] przewidziana w ustawie, stosowana przez sądy, ujemna reakcja na popełnione przestępstwo, polegająca na zadaniu sprawcy osobistej dolegliwości mającej na celu zadośćuczynienie społecznemu poczuciu sprawiedliwości oraz wypełniającej cele prewencyjne" - Z. SIENkIEwICZ. W: Prawo karne materialne..., s. 343.

50 Z. SIENKIEWICZ. W: Prawo karne materialne..., s. 417.

${ }^{51}$ Ustawa z dnia 6 czerwca 1997 r. - Kodeks karny wykonawczy (Dz.U. 1997, nr 90, poz. 557 ze zm.). 
wa łaski wobec osoby skazanej prawomocnym wyrokiem sądu państwa obcego jest rażącym wtargnięciem w zakres kompetencji państwa obcego realizowanego przez jego instytucje sądownicze - wynikającego z jego suwerennej władzy, z której to wynika jego ius puniendi.

Reasumując, na gruncie polskiego prawa nie jest możliwe zastosowanie prawa łaski wobec osoby, której kara została orzeczona wyrokiem sądu zagranicznego, a jedynie przyjęta do wykonania na terytorium RP. Powyższe stanowisko może być trudne do zaakceptowania dla tych, którzy optować będą za poglądem podzielanym chociażby przez P. Czarnego ${ }^{52}$, czyli stanowiska omnipotentnego prawa łaski. Nie można bowiem wykluczyć wysunięcia kontrargumentu mówiącego, że państwo obywatelstwa (w tym przypadku Polska) posiada, właśnie przez fakt istnienia łącznika jurysdykcji personalnej, niejako - dość, niestety, nieelegancko ujmując - swobodę wobec decydowania o losie swego obywatela, a zatem prezydent (czy inna głowa państwa mutatis mutandis) może w zakresie swojej dyskrecjonalnej władzy zastosować prawo łaski. Decyzję właściwej głowy państwa można argumentować także humanitarnymi względami ułaskawienia, z którego to samego charakteru wynika, że jest to działanie in plus, a nie in minus dla jednostki. Oczywiście ten argument zasługuje na wzięcie go pod uwagę. Wszak wszelkie działania pro libertate wobec jednostki przemawiają do umysłów i serc wszystkich podległych władzy państwowej. Jednakże nie można tracić z pola widzenia faktu, że wydany obywatel z jakiejś przyczyny stanowił przedmiot toczącego się wobec niego postępowania karnego przed sądami państwa obcego. W przypadku skazania prawomocnym orzeczeniem - które podlega wykonaniu na terenie RP na mocy obowiązującej strony umowy międzynarodowej - istnieje zatem pewność, iż jest on sprawcą przestępstwa. Wszak jeśli RP zgodziła się $\mathrm{w}$ dobrej wierze na zawarcie umowy międzynarodowej o przekazaniu skazanych i wykonywaniu ich kar na jej terenie, to istnieje konieczność przestrzegania tego zobowiązania. Rzeczpospolita może oczywiście wypowiedzieć ową umowę międzynarodową na zasadach ogólnych, jednakże skutki tego wypowiedzenia będą miały charakter ex nunc, nie ex tunc.

Niemniej jednak wobec powyższych rozważań konieczne jest zasygnalizowanie swojego rodzaju zastrzeżenia. Mianowicie państwa (państwo wydające oraz państwo przyjmujące) na mocy umowy międzynarodowej mogą ową materię uregulować w sposób odmienny z uwagi na dyspozytywny charakter omawianych rozwiązań. Najlepszym dowodem powyższego jest już wcześniej powoływana Decyzja Ramowa Rady Europejskiej oraz wynikające z niej konsekwencje na gruncie prawa międzynarodowego oraz promieniującej na rodzime porządki prawne.

52 P. CZarny: Komentarz... 


\section{Prawo łaski wobec wyroku Międzynarodowego Sądu Karnego ${ }^{53}$}

Na przestrzeni ostatnich dekad społeczność międzynarodowa uznała za konieczne powołanie niezawisłych i niezależnych organów, które będą czuwać nad przestrzeganiem norm prawa międzynarodowego o charakterze erga omnes, mających za zadanie chronić ludzkość przed sprawcami najpotworniejszych przestępstw - zbrodni prawa międzynarodowego

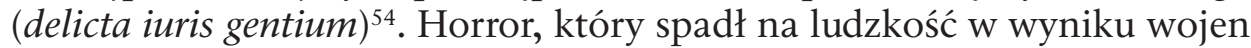
światowych, skłonił społeczność międzynarodową do podjęcia stosownych kroków. Powołane zostały specjalne organy, czy to o charakterze doraźnym, jak np. Trybunał Norymberski czy Tokijski, czy też stałym, jak - ikona sądownictwa międzynarodowego karnego - Międzynarodowy Trybunał Karny. Nie jest do końca nieuzasadniony sceptycyzm w tym zakresie. Wszak prędzej czy później padnie pytanie o sens istnienia międzynarodowych sądów karnych. Mając bowiem na uwadze to, że sam ich byt zależy od woli państw, wszak z dużą dozą prawdopodobieństwa (a nawet pewności) można zauważyć, że w przypadku braku chęci i woli, bądź ich utraty, ze strony podmiotów pierwotnych prawa międzynarodowego niemożliwe stanie się powoływanie oraz funkcjonowanie takich organów. W związku z zagadnieniem dotyczącym sensu istnienia międzynarodowego sądownictwa karnego trafnie (i nieco poetycko) wskazują P. Hofmański i H. Kuczyńska, że „odpowiedzi zdaje się udzielać historia pełna unicestwionych ludzkich istnień, nieopisanych cierpień tysięcy i milionów ludzi oraz popełnionych na wielką skalę okrucieństw, za które nikt i nigdy nie poniósł odpowiedzialności" ${ }^{55}$. W tej części opracowania zostanie omówiona możliwość zastosowania prawa łaski wobec osoby, której została orzeczona kara za popełnienie zbrodni stypizowanej w aktach prawa międzynarodowego.

53 Już sam termin „międzynarodowe prawo karne” nie jest przedmiotem powszechnej zgody. Można go bowiem interpretować dwojako - w sposób szeroki i wąski. P. Hofmański i H. Kuczyńska wskazują, iż termin ten ujmowany sensu largo można definiować jako „normy prawa międzynarodowego dotyczące karania i ścigania czynów zabronionych”, które ujęte wraz z normami prawa krajowego „dotyczą "postępowania z elementem zagranicznym «”. Sensu stricto autorzy Ci wskazują, iż „międzynarodowe prawo karne jest to prawo stosowane przez międzynarodowe trybunały karne, które dotyczy odpowiedzialności karnej jednostek za zbrodnie prawa międzynarodowego na forum międzynarodowym oraz postępowania w sprawach o te zbrodnie" - P. HofMańsKi, H. KuczYŃsKa: Międzynarodowe prawo karne. Warszawa 2020, s. 17. W niniejszym artykule autor mówiąc o międzynarodowym prawie karnym, ma na myśli jego rozumienie zgodne z drugą z podanych definicji.

54 Por. W. CZapliński, A. Wyrozumska: Prawo międzynarodowe publiczne..., s. 46-50.

55 P. Hofmański, H. KuCZYŃsKa: Międzynarodowe prawo karne..., s. 18. 
Międzynarodowe sądy karne, takie jak np. Międzynarodowy Trybunał Karny czy Międzynarodowy Trybunał Karny dla byłej Jugosławii ${ }^{56}$, bądź umiędzynarodowione sądy karne ${ }^{57}$, jak np. Rezydualny Specjalny Sąd dla Sierra Leone albo Nadzwyczajna Izba Sądów Kambodży, nie działają niestety - $\mathrm{w}$ próżni. Nie posiadają one organów, które czuwałyby nad wykonaniem ich orzeczeń. Egzekucja wyroku spoczywa w pełni na państwach-stronach danej umowy międzynarodowej ${ }^{58}$, które dany trybunał powołały, bądź też w przypadku sądu hybrydalnego - na organach państwa, w ramach którego ów umiędzynarodowiony organ działa. Ponadto powoływane są one $\mathrm{w}$ drodze umów międzynarodowych, w których to państwa-strony tychże umów decydują o zakresie ich kognicji, a także procedurze, na podstawie której będą działać. Należy także podkreślić,

56 Tzw. międzynarodowe sądy karne ad hoc szerzej zob. B. KrzAn: Międzynarodowe sady karne ad hoc. W: Wspótczesne sqdownictwo międzynarodowe. Zagadnienia instytucjonalne. Red. J. KolasA. Wrocław 2009, s. 191 i nast.

57 Są one niekiedy nazywane sądami hybrydowymi. Łączą w sobie cechy sądu państwowego oraz sądu międzynarodowego. Powoływane są na mocy porozumienia państwa, w którym doszło do naruszenia zobowiązań prawnomiędzynarodowych o charakterze erga omnes. Hybrydalny charakter owych sądów przejawia się w tym, iż nie są to klasyczne sądy międzynarodowe per se, wszak mogą działać w ramach wewnątrzpaństwowego systemu sądownictwa - np. jako specjalna izba sądu, jak w przypadku kambodżańskim bądź też mogą być poza strukturą państwową, jak w przypadku Specjalnego Trybunału dla Sierra Leone. Niemniej jednak zawierają one w sobie element międzynarodowy, który sprowadza się do mieszanego składu organów. Wchodzą weń przedstawiciele państw członkowskich ONZ na równi z przedstawicielami państwa, w którym doszło do owych naruszeń. Taki rodzaj sądownictwa stosuje się w przypadku, gdy w państwie naruszeń istnieje chociażby minimalna infrastruktura sądowa, a także chęć „rozliczenia” przeszłości. Umiędzynarodowiony charakter sądu wpływa na to, że istnieją większe szanse, iż procesy prowadzone przed tymi sądami będą się toczyć w oparciu o zasadę fair trail, a także będą niezmącone żadnymi naciskami ze stron czy to organów władzy państwowej, czy też opinii publicznej.

${ }^{58}$ Sądownicze organy międzynarodowe klasycznie powoływane są na podstawie umowy międzynarodowej. Owo stwierdzenie bardziej oddaje swojego rodzaju zwyczaj w potocznym tego słowa rozumieniu - aniżeli obraz swoistej zasady. Międzynarodowy Trybunał Karny ds. byłej Jugosławii został powołany na podstawie uchwały Rady Bezpieczeństwa ONZ. Nie jest pozbawiony racji pogląd A. Kozłowskiego, który pisze, iż „i tutaj można wskazać na pośredni prymat Karty ONZ, która określa zakres kompetencji organu powołującego do życia ten konkretny trybunał". Zatem charakter powołania do życia takiego trybunału będzie czerpał swą legitymację z dwóch źródeł. Po pierwsze z umowy międzynarodowej (jaką w tym przypadku jest Karta ONZ), wyznaczającej organ kompetentny do podjęcia właściwej w przedmiocie uchwały, która będzie miała charakter wtórny względem umowy międzynarodowej. Po drugie trybunał będzie czerpał legitymację także z uchwały właściwego organu. W związku z tym uprawnione wydaje się stanowisko, iż ów akt organu będzie miał charakter wykonawczy względem umowy międzynarodowej, na mocy której został on podjęty, oraz będzie od niej niższy rangą. Por. A. KozŁowski: Międzynarodowy Trybunat Sprawiedliwości. W: Sądownictwo..., s. 14. 
że to państwa-strony danej umowy międzynarodowej (na mocy której powoływany jest do życia organ sądowniczy o charakterze międzynarodowym) decydują o jego bycie, tj. powołaniu oraz rozwiązaniu. Organ funkcjonuje, dopóki między państwami istnieje konsensus mówiący o chęci utrzymywania go „przy życiu”. Rację ma A. Kozłowski, wskazując, iż norma prawa międzynarodowego - czyli także norma, na podstawie której tworzony jest ponadnarodowy sąd - czerpie legitymizującą ją moc z konsensusu państwa; pomocniczo swą rolę w tym zakresie pełnią zasady ogólne prawa międzynarodowego publicznego - dobrej wiary oraz pacta sunt servanda ${ }^{59}$. Powyższe nie oznacza oczywiście tego, iż państwa-strony umowy mogą w jakiś sposób ingerować w treść wyroków czy orzeczeń wydawanych przez te organy, wszak są one niezawisłe i niezależne w sprawowaniu przekazanej im władzy ${ }^{60}$. Kwestią, obok której nie można przejść bezrefleksyjnie, jest aspekt wykonywania przez międzynarodowe sądy karne władzy państwowej w zakresie ius puniendi. Państwa powołując taki sąd międzynarodowy (ekwiwalentnie umiędzynarodowiony w zgodzie z Kartą ONZ), przekazują temu organowi pewną cząstkę swej suwerennej władzy, a mianowicie prawo sądzenia oraz karania podlegających im jednostek w sytuacji, gdy zostanie im zarzucone, a następnie przypisane popełnienie zbrodni prawa międzynarodowego. Obrazowo opisując, wszystkie państwa oddają niejako „cegiełki”, które razem ujęte tworzą podstawę sprawowania tejże władzy przez powołany organ. Zatem międzynarodowe sądy karne nie czerpią swojej legitymacji z władzy suwerennej jednego państwa, a z wielu suwerennych władz. Uprawnia to do przyjęcia koncepcji wykonywania przez nie jurysdykcji uniwersalnej (wszechświatowej) ${ }^{61}$. Ażeby nieco rozjaśnić powyższy pogląd, konieczne

59 A. KozŁowski: Interpretacja systemowa prawa międzynarodowego. W: Rozwój prawa międzynarodowego - jedność czy fragmentacja?. Red. A. KozŁowski, J. KolasA. Wrocław 2007, s. 175.

${ }^{60}$ Odpowiednie w tym przedmiocie zapisy znajdują się m.in. w Statucie Rzymskim Międzynarodowego Trybunału Karnego - art. 40 ust. 1, a także w art. 13 ust. 1 Statutu Specjalnego Rezydualnego Sądu dla Sierra Leone. W tym przedmiocie zob. także P. Hofmański, H. Kuczyńska: Międzynarodowe prawo karne..., s. 162 oraz Ch. Staker, H. Автані, R. Young: Article 40. In: The Rome Statute of International Criminal Court. A Commentary. Eds. O. Triffterer, K. Ambos. Munich-Oxford 2015, s. 1253-1257.

${ }^{61}$ Podobnie P. Hofmański, H. KuczyŃsKa: Międzynarodowe prawo karne..., s. 63-64. W ustawodawstwie państw może znaleźć się norma nakazująca organom tegoż państwa działanie w celu zastosowania represji wszechświatowej. Ma to związek z koniecznością ścigania i karania sprawców czynów zabronionych stypizowanych w umowach międzynarodowych. Taka sytuacja ma miejsce w polskim ustawodawstwie - arg. ex art. 113 k.k. $\mathrm{W}$ rodzimej regulacji ustawodawca przewiduje konieczność osądzenia sprawcy wówczas, gdy nie postanowiono go wydać organom innego państwa czy też organom międzynarodowym, zob. także J. GIEzEK: Obowiązywanie polskiej ustawy karnej za przestępstwa popetnione za granica. W: Prawo karne materialne..., s. 82 oraz R. STEFAńsKi: Prawo karne ma- 
jest pochylenie się - choć, niestety, z uwagi na charakter i ramy niniejszego artykułu w dużym uproszczeniu - nad kwestią pochodzenia władzy do karania, którą dzierży każde państwo wobec jednostek mu podległych. Posługując się teorią umowy społecznej jako leżącej u podstaw samego istnienia państwa, należy wskazać, że to na mocy tejże umowy jednostki oddały swoją suwerenność na rzecz państwa, które w ich imieniu wykonuje władzę „dla dobra ogółu”. Przenosząc tę teorię na grunt sądownictwa międzynarodowego, można wskazać, iż to państwa oddają swą suwerenną władzę (uprzednio im powierzoną) w celu wykonywania niejako „za nie" władzy w tym obszarze. W zakres kognicji międzynarodowych sądów karnych wchodzi możliwość sądzenia i karania najpotworniejszych zbrodni, jakich można dokonać przeciwko jednostkom. Wykonują one zatem swą władzę nie w imieniu państw, które je powołały, a w imieniu społeczności międzynarodowej in genere - rozumianej jako kolektyw jednostek, które na mocy umowy społecznej upoważniły ich przedstawicieli do przekazania tejże kompetencji $\mathrm{w}$ ich imieniu organom międzynarodowym. Szczególna zatem jest rola sądu międzynarodowego orzekającego w sprawach o delicta iuris gentium. Wszak ma on władzę w zakresie ius puniendi społeczności międzynarodowej, a nie w zakresie suwerennego państwa. Wysunąć także można dość śmiałą tezę - mając w pamięci komplementarny charakter międzynarodowego sądownictwa karnego ${ }^{62}-$ mówiącą, iż sąd krajowy wydający wyrok w oparciu o właściwe umowy międzynarodowe czy nawet przepisy krajowe przewidujące odpowiedzialność jednostki za zbrodnie międzynarodowe feruje owo orzeczenie nie w imieniu swego państwa, a w imieniu społeczności międzynarodowej. Dualizm roli sądu orzekającego w sprawie o zbrodnię międzynarodową dostrzegł Sąd Najwyższy Izraela w sprawie A. Eichmanna ${ }^{63}$.

W związku z powyższym uprawniona wydaje się odpowiedź udzielona wcześniej - $\mathrm{w}$ polskim przypadku prezydenckie prawo łaski nie ma zastosowania wobec skazanego wyrokiem międzynarodowego sądu karnego.

terialne..., s. 79 i nast. Jednakże konieczne jest zauważenie, że właściwą formą powinno być wydanie takiej osoby organom międzynarodowym. Dopiero wtedy, gdy takie organy postanowiłyby - z jakiegoś powodu - nie wszczynać przeciwko tej osobie postępowania, winno się uruchomić proces karny wobec jednostki na gruncie prawa polskiego. Z uwagi jednak na charakter i ograniczenia niniejszego opracowania dokładne omówienie problematyki kolizji zasady represji wszechświatowej z ustawodawstwem krajowym nie jest możliwe, wszak przekroczyłoby to ramy tegoż artykułu.

${ }^{62}$ Szerzej P. HofmŃski, H. KuczyŃsKa: Międzynarodowe prawo karne..., s. 64-69.

63 „The State prosecuting and punishing the perpetrator of an international crime shall act solely as an authority and representative of the international community which administers justice for violation of the prohibition established by the law of nations" Attorney-General of the Government of Israel v. Eichmann, Israeli Supreme Court, 29.05.1962. "International Law Review" 1968, vol. 36. 
Potwierdzeniem praktyki państw $\mathrm{w}$ tym zakresie wydają się przyjmowane w statutach międzynarodowych sądów karnych (arg. ex. m.in. art. 105 ust. 1 Statutu Rzymskiego ${ }^{64}$, a także art. 10 Statutu Specjalnego Rezydualnego Sądu dla Sierra Leone ${ }^{65}$ ) specjalne prowizje wyłączające możliwość stosowania zarówno amnestii, jak i prawa łaski wobec „zbrodniarzy międzynarodowych”. Powyższe pozwala wskazać, że za omawianą praktyką idzie także opinio iuris stanowiące drugi konieczny element do powstania normy zwyczajowej prawa międzynarodowego publicznego ${ }^{66}$. P. Hofmański i H. Kuczyńska słusznie wskazują na źródło pomocnicze tegoż zwyczaju powszechnie uznany obowiązek ścigania zbrodni międzynarodowych ${ }^{67}$. Ułaskawienie skazanego, czy to na mocy sądu międzynarodowego, czy sądu krajowego, w sprawie o zbrodnię międzynarodową byłoby pogwałceniem prawa międzynarodowego, co skutkowałoby naruszeniem Konstytucji (arg. ex art. 9 Konstytucji). Jednakże nie oznacza to, iż głowy innych państw mogą stosować wobec takich osób prawo łaski. Wszak powyższy wywód mutatis mutandis dotyczy wszystkich organów władnych do stosowania ius agratiandi. Każdy z nich jest bowiem zobowiązywany do przestrzegania norm ius cogens prawa międzynarodowego.

\section{Dualistyczny charakter prawa łaski}

$\mathrm{Na}$ marginesie powyższych rozważań można podjąć się stworzenia dychotomicznego podziału zastosowania prawa łaski, dokonanego ze względu na skutek, jakim byłoby ułaskawienie oportunistyczne tudzież ekwiwalentnie humanitarne.

${ }^{64}$ Rzymski Statut Międzynarodowego Trybunału Karnego sporządzony w Rzymie dnia 17 lipca 1998 r. (Dz.U. 2003, nr 78, poz. 708) [dalej jako: Statut Rzymski].

${ }^{65}$ Statute of the Special Court for the Sierra Leone [dalej jako: Statut Specjalnego Rezydualnego Sądu dla Sierra Leone]. Źródło: http://www.rscsl.org/Documents/scsl-statute.pdf [data dostępu: 18.02.2021].

${ }^{66}$ Więcej o tworzeniu się zwyczaju w prawie międzynarodowym publicznym W. Czaplíśri, A. Wyrozumska: Prawo międzynarodowe publiczne..., s. 97-129 oraz W. GóralczyK, S. Sawicki: Prawo międzynarodowe publiczne..., 96-105.

${ }^{67}$ P. Hofmański, H. KuczYŃsKa: Międzynarodowe prawo karne..., s. 109 - autorzy ci wskazują na pewnego rodzaju wyjątki od tej powszechnej zasady, przewidujące ekstraordynarne sytuacje, w których odpowiedni organ może w ściśle wskazany sposób zmodyfikować orzeczoną wobec międzynarodowego zbrodniarza karę. Wyjątek ten może budzić pewne - skądinąd uzasadnione - kontrowersje. Wątpliwe jest ustanawianie swoistego prawa łaski dla międzynarodowych zbrodniarzy, bowiem państwa kierują się raczej pragmatyzmem, a nie obowiązkiem poszanowania praw jednostek. Dochodzi tu do kolizji zasad prawa międzynarodowego - zasady konsensualizmu oraz obowiązkowej prosekucji zbrodni międzynarodowych. Jednakże z uwagi na ramy niniejszej pracy oraz jej charakter rozważenia w tym przedmiocie nie zostaną podjęte. 
Pierwsze z nich ma miejsce $\mathrm{w}$ sytuacji, gdy uprawniony do stosowania prawa łaski stosuje je wobec jednostki, która ze względu na koneksje osobiste czy też z uwagi na „szczególny interes państwa”, rozumiany tutaj jako wypaczenie tegoż pojęcia, zostaje w sposób zupełny „wybawiona od kary". Oportunistyczny przejaw stosowania prawa łaski powinien być bezwzględnie zakazany de lege ferenda na gruncie prawa krajowego, tak jak ma to miejsce na gruncie prawa międzynarodowego $\mathrm{z}$ uwagi na zasadę obowiązkowej prosekucji zbrodni międzynarodowych mającej charakter normy ius cogens i zobowiązania międzynarodowego erga omnes. Możliwość zastosowania oportunistycznego prawa łaski powinna być bezwzględnie wyłączona w przypadku skazanego wyrokiem sądu krajowego za przestępstwo z ,katalogu krajowego”, zaś jest ona wyłączona w sytuacji skazania wyrokiem państwa obcego (i przyjęcia kary do wykonania), a także skazania za międzynarodową zbrodnię - nieistotne, czy owo orzeczenie wydał sąd międzynarodowy czy krajowy. Ważne jest to, za co dana osoba została skazana, wszak to sam czyn jednostki determinuje wyłączenie możliwości zastosowania wobec niej prawa łaski decyzją jednostronną organu uprawnionego w danym państwie do jej stosowania ${ }^{68}$, które można skrótowo określić jako zakaz stosowania oportunistycznego prawa łaski.

Prawo łaski przejawiające się w ułaskawieniu ujętym w aspekcie humanitarnym sprowadza się do pierwotnego rozumienia ius agratiandi jako swoistego „wentyla bezpieczeństwa” wobec surowości orzeczonej kary. Ów aspekt wpisuje się w klasyczne ujęcie prawa łaski, które pozwala na złagodzenie kary czy też „wybawienie” od niej danej osoby z uwagi na szczególnie humanitarne - nacisk powinien być położony na wymienione przymiotniki - względy, które uzasadniają jego zastosowanie in concreto. Ponadto należy wskazać, że ta sytuacja winna mieć charakter wyjątku, a nie reguły. Jeśli te przesłanki kumulatywnie zostaną wypełnione, humanitarne prawo łaski będzie pozostawać w zakresie kognicji organów uprawnionych do jego stosowania, tj. organu wyznaczonego przez suwerena w danym państwie. Prawo do stosowania ułaskawienia humanitarnego może być przekazane na mocy decyzji suwerennego podmiotu prawa międzynarodowego właściwemu organowi państwa obcego. Taka sytuacja ma miejsce np. w Unii Europejskiej (arg. ex. art. 19 ust. 1 Decyzji

${ }^{68}$ De lege ferenda nie pozostaje poza możliwością wyobrażenia podjęcie przez społeczność międzynarodową decyzji o powołaniu do życia wszechświatowego organu, w którego zakresie kompetencji mogłoby znajdować się stosowanie prawa łaski „wszechświatowej”, stojącej w opozycji do represji uniwersalnej. Niemniej jednak wydaje się to równie prawdopodobne co „wzejście Słońca na zachodzie, a zajście na wschodzie”, zaś rozważania w tym przedmiocie - sprowadzając nieco do absurdu - przypominałyby raczej prawnicze science-fiction aniżeli rzetelną literaturę naukową. 
Ramowej Rady Europejskiej). Owo przekazanie może nastąpić na mocy umowy międzynarodowej sensu largo, ale zdaje się nie być wyłączona możliwość wytworzenia się zwyczaju w tym zakresie.

Organ państwa, który stosuje oportunistyczne, ale także pozbawione podstawy faktycznej i prawnej humanitarne prawo łaski, czy to wobec obywatela państwa obcego, czy też własnego oraz w sytuacji tzw. zbrodniarza międzynarodowego, jeśli ich kara została przyjęta do wykonania na terenie tegoż państwa, działa w naruszeniu powszechnie obowiązującego prawa międzynarodowego. Jego działanie ma charakter ultra vires $\mathrm{z}$ uwagi na obowiązywanie zasady dobrej wiary w przypadku delicta iuris gentium, zaś przyjęcie do wykonania kary, a następnie ułaskawienie skazanego - bez wyraźnej zgody państwa wydającego - jest naruszeniem zasady dobrej wiary, a także (przede wszystkim) zasady suwerennej równości państw. Wszak organ państwa „ułaskawiającego” uzurpuje sobie suwerenne prawo łaski państwa wydającego.

\section{Podsumowanie}

$\mathrm{W}$ niniejszym artykule - $\mathrm{w}$ dużej mierze - zostało przyjęte spektrum Polonia contra Mundi. Nie oznacza to jednak, iż prawo łaski stosowane przez organy państw obcych - w sytuacji z „,czynnikiem międzynarodowym" - ma szerszy zakres. Można wysunąc śmiałą tezę, iż prawo łaski suwerennego państwa (głowy państwa) wobec prawa międzynarodowego będzie miało tożsamy zakres w każdym państwie. Stosowanie prawa łaski jest wpisane w trzon suwerennego władztwa państwowego jako takiego. Zakres stosowania tego prawa (w odniesieniu do przestępstw powszechnych) między państwami mogą modulować zainteresowane strony. Państwa są władne to czynić na mocy porozumień międzynarodowych, ale także poprzez zezwolenie na powstanie między nimi zwyczaju międzynarodowego opartego na zasadzie konsensualizmu. Zatem nie można uniknąć wniosku, że pomiędzy państwem A i państwem B prawo łaski będzie miało charakter szeroki, niemalże nieograniczony, w analogicznej sytuacji między państwem B i C zakres ius agratiandi będzie wyglądał już zgoła inaczej, natomiast w sytuacji zbrodni międzynarodowych zakres stosowania tego prawa może się poszerzyć (zawęzić) tylko po wejściu w życie normy o charakterze ius cogens i zasięgu erga omnes, która uprawniałaby członków społeczności międzynarodowej do stosowania prawa łaski. Jednakże de lege lata, in abstracto przyjęcie kary do wykonania - orzeczonej wyrokiem sądu międzynarodowego bądź sądu państwa obcego - i następcze jej wykonywanie stanowi szereg czynności czysto technicznych związanych ze sprawowaniem wymiaru sprawiedli- 
wości. Państwo wykonujące ma obowiązek wykonywania tejże kary, nie ma zaś uprawnienia do ingerencji w nią - mowa tu o ingerencji, która mogłaby spowodować zaprzestanie wykonywania kary i „uwolnienie” skazanego.

Powyższe rozważania można sprowadzić do następującej konstatacji przypisywanie przymiotu omnipotencji prawu łaski jest chybione.

\section{Bibliografia}

\section{Literatura}

Balicki R.: Komentarz do art. 139 Konstytucji Rzeczpospolitej Polskiej z 1997 r. W: Konstytucje Rzeczpospolitej oraz komentarz do Konstytucji RP z 1997 r. Red. J. Boć. Wrocław 1998.

Banaszak B.: Prawo konstytucyjne. Warszawa 2015.

BARWINA Z.: Przepis art. 114 § 4 kodeksu karnego $w$ świetle konwencji o przekazywaniu osób skazanych z dnia 21 marca 1983 r. CPKNP 2009, z. 1.

Boć J.: Komentarz do art. 139 Konstytucji Rzeczpospolitej Polskiej z 1997 r. W: Konstytucje Rzeczpospolitej oraz komentarz do Konstytucji RP z 1997 r. Red. IDEM. Wrocław 1998.

CHORĄżEwska A.: Model prezydentury $w$ praktyce politycznej po wejściu $w$ życie Konstytucji RP z 1997 r. Warszawa 2008.

CIEŚLAK M.: O węzłowych pojęciach zwiazanych z sensem kary. NP 1969, nr 2.

CZAPLIŃski W., Wyrozumska A.: Prawo międzynarodowe publiczne. Warszawa 2014.

CZARnY P.: Komentarz do art. 139 Konstytucji Rzeczpospolitej Polskiej. W: Konstytucja Rzeczpospolitej Polskiej. Komentarz. Red. P. Tuleja. LEX 2019.

GARDOCKI L.: Prawo karne. Warszawa 1998.

GIEZEK J:: Obowiqzywanie polskiej ustawy karnej za przestępstwa popetnione za granica. W: Prawo karne materialne. Część ogólna i szczególna. Red. M. BoJARSKI. Warszawa 2020.

GóRalczyK W., Sawicki S.: Prawo międzynarodowe publiczne. Warszawa 2004.

GóRecki D.: Prezydent Rzeczypospolitej Polskiej. W: Polskie prawo konstytucyjne. Red. IDEM. Warszawa 2015.

GrZegorczyK T.: Kodeks postępowania karnego. Komentarz. Warszawa 2008.

HARRIS J., REDMOND L.: Executive Clemency: The Lethal Absence of Hope. "American University Criminal Law Brief” 2007.

HofMAŃski P., Kuczý́sKa H.: Międzynarodowe prawo karne. Warszawa 2020.

Hofmański P., SAdZIK E., ZgryzeK K.: Kodeks postępowania karnego. Komentarz do artykułów 468-682. T. III. Red. P. HofmaŃsKI. Wyd. 4. Warszawa 2012.

Hypś S.: Komentarz do rozdziału VIII kodeksu karnego. W: Kodeks karny. Komentarz. Red. A. Grzé́KоWIAK. Legalis 2021.

JeLLINEK G.: Allgemeine Staatslehre. Berlin 1914.

KaCZMARCZyK-KŁaK K.: Postępowanie ułaskawieniowe $w$ świetle Konstytucji RP na tle porównawczym. IN 2001, nr 3. 
KaCZMARCZYK-KŁAK K.: Ułaskawienie w prawie polskim a Międzynarodowy Pakt Praw Obywatelskich i Politycznych oraz Konwencja o ochronie praw człowieka i podstawowych wolności. „Problemy Współczesnego Prawa Międzynarodowego, Europejskiego i Porównawczego" 2012, vol. X.

Kardas P., GiezeK J.: Konstytucyjne podstawy prezydenckiego prawa łaski a możliwość stosowania tzw. abolicji indywidualnej. Pal. 2016, nr 1-2.

KIEROŃCZYK P.: Prezydent RP - zadania i kompetencje. W: Leksykon prawa konstytucyjnego. 100 podstawowych pojęć. Red. A. SzmYT. Warszawa 2016.

KŁąCZYŃsKa N.: Komentarz do art. 114 k.k., W: Kodeks karny. Część ogólna. Komentarz. Red. J. GiEzeK. Warszawa 2007.

KŁączyńska-KŁaK K.: Prawo taski w Polsce na tle porównawczym. Dawniej i wspótcześnie. Rzeszów 2013.

KMIECIK R.: Jeszcze raz w sprawie abolicji indywidualnej. Prok. i Pr. 2017, nr 12.

Kosturbiec J.: Nauka o państwie w myśli Georga Jellinka. Lublin 2015.

KozŁowsKi A.: Interpretacja systemowa prawa międzynarodowego. W: Rozwój prawa międzynarodowego - jedność czy fragmentacja?. Red. A. KozŁowsKi, J. KolasA. Wrocław 2007.

KozŁowski K.: Prawo łaski Prezydenta RP. Warszawa 2013.

KrZAN B.: Międzynarodowe sądy karne ad hoc. W: Wspótczesne sądownictwo międzynarodowe. Zagadnienia instytucjonalne. Red. J. KolasA. Wrocław 2009.

KrZYMusKi E.: System Prawa Karnego. Kraków 1921.

Kunicka-Michalska B.: Komentarz do art. 114 k.k. W: Kodeks karny. Część ogólna. Komentarz. Red. G. RejMAn. Warszawa 1999.

KwiatKowski W.: Federalne prawo łaski w Stanach Zjednoczonych Ameryki. „Zeszyty Prawnicze” 2015.

KwIATKowsKi W.: Prawo taski na poziomie stanowym w USA. „Zeszyty Prawnicze” 2016.

LIs E.: Zasada dobrej wiary $w$ prawie międzynarodowym. „Studia Iuridica Lublinensia" 2016, vol. XXV(1).

Makowski W.: Prawo karne. Część ogólna. Warszawa 1920.

MaŁajny R.: Prezydent RP. W: Polskie prawo konstytucyjne na tle porównawczym. Red. IDEM. Warszawa 2013.

MAReK A.: Kodeks karny. Komentarz. Warszawa 2007.

MareK A.: Prawo karne. Warszawa 2011.

MojaK R.: Instytucja Prezydenta RP w okresie przeksztatceń ustrojowych 1989-1992. Warszawa 1994.

MurzYNOwsKi A.: Ułaskawienie w Polsce Ludowej. Warszawa 1965.

Nowicki K.: Postępowania następcze. W: Proces karny. Red. J. SkorupKA. Warszawa 2017.

PŁachтA M.: Zagadnienia ekstradycyjne w prawie polskim. „Studia Europejskie” 1999 , nr 2.

POLIT-LANGIEROWICz K.: Wzajemne uznawanie orzeczeń karnych między państwami Unii Europejskiej. Prok. i Pr. 2008, nr 3.

RagalewsKi J.: Komentarz do art. 114 k.k. W: Kodeks karny. Częśćogólna. Komentarz. Red. G. Bogdan et al. Kraków 2004. 
Rosicki R.: O suwerenności. „Przegląd Naukowo-Metodyczny. Edukacja dla bezpieczeństwa” 2010, nr 4.

SCHEFfler T.: O ius puniendi uwag kilka. W: Varia doctrinalia. Red. Ł. MACHAJ. Wrocław 2012.

SIENKIEWICZ Z.: Środki związane z poddaniem sprawcy próbie. W: Prawo karne materialne. Czę̧ść ogólna i szczególna. Red. M. BojarsKI. Warszawa 2020.

Sienkiewicz Z.: Utaskawienie. W: Prawo karne materialne. Część ogólna i szczególna. Red. M. BOJARSKI. Warszawa 2020.

Sтасношіак S.: Utaskawienie w przepisach k.p.k. „Wojskowy Przegląd Prawniczy” 2000 , nr 2.

Staker Ch., АвтAhi H., Young R.: Article 40. In: The Rome Statute of International Criminal Court. A Commentary. Eds. O. TriffTERer, K. Ambos. Munich-Oxford 2015.

Stefański R.: Prawo karne materialne. Część ogólna. Warszawa 2008.

ŚwIDA W.: Prawo karne. Warszawa 1978.

Waltoś S.: Proces karny. Zarys systemu. Warszawa 2002.

Weinofe H.: Legislative Pardons. Another View. "California Law Review" 1939.

Wilk L.: Prawo łaski a sprawiedliwość karania - refleksja filozoficznoprawna. Probl. Prawa Karnego 2000, nr 23.

Wiszowaty M.: Prawo łaski Prezydenta III RP jako realizacja funkcji przedstawiciela suwerennego narodu oraz strażnika bezpieczeństwa państwa. Uwagi po uchwale składu siedmiu sędziów Sądu Najwyższego z dnia 31 maja 2017 r. (sygn. akt I KZP 7/17). „Gdańskie Studia Prawnicze” 2018.

Wróbel W., Zoll A.: Polskie prawo karne. Część ogólna. Kraków 2014.

\section{Akty prawne}

Konstytucja Rzeczypospolitej Polskiej z dnia 2 kwietnia 1997 r. (Dz.U. 1997, nr 78, poz. 483 ze zm.).

Ustawa z dnia 6 czerwca 1997 r. - Kodeks karny (Dz.U. 1997, nr 88, poz. 553 ze zm.).

Ustawa z dnia 6 czerwca 1997 r. - Kodeks postępowania karnego (Dz.U. 1997, nr 89, poz. 555 ze zm.).

Ustawa z dnia 6 czerwca 1997 r. - Kodeks karny wykonawczy (Dz.U. 1997, nr 90, poz. 557 ze zm.).

Międzynarodowy Pakt Praw Obywatelskich i Politycznych otwarty do podpisu w Nowym Jorku dnia 19 grudnia 1966 r. (Dz.U. 1977, nr 38, poz. 167).

Rzymski Statut Międzynarodowego Trybunału Karnego sporządzony w Rzymie dnia 17 lipca 1998 r. (Dz.U. 2003, nr 78, poz. 708).

Decyzja Ramowa Rady 2008/909/WSiSW z dnia 27 listopada 2008 r. o stosowaniu zasady wzajemnego uznawania wyroków skazujących na karę pozbawienia wolności lub inny środek polegający na pozbawieniu wolności - w celu wykonania tych wyroków w Unii Europejskiej. 


\section{Orzecznictwo}

Israeli Supreme Court, 29.05.1962. Attorney-General of the Government of Israel v. Eichmann. "International Law Review" 1968, vol. 36.

Post. SN z dnia 2 maja 1975 r., II KO 5/75. OSP 1976, z. 4, poz. 73.

Post. SN z dnia 29 listopada 2006 r., I KZP 26/06. OSNKW 2006, nr 12, poz. 109; LEX nr 203987.

Post. SA w Krakowie z dnia 8 kwietnia 2010 r., II AKz 114/10. LEX nr 590590.

\section{Źródła internetowe}

Statute of the Special Court for the Sierra Leone. Źródło: http://www.rscsl.org/ Documents/scsl-statute.pdf [dostęp: 18.02.2021]. 